\title{
Why Is the Grammar-translation Method Still Alive in the Arab World? Teachers' Beliefs and Its implications for EFL Teacher Education
}

\author{
Hussein M. Assalahi \\ English Language Institute, King Abdulaziz University, Jeddah, Saudi Arabia
}

\begin{abstract}
Language teachers' agency to their belief system has been widely reported to influence classroom teaching practices. Whilst the bulk of research has dealt with second language learner teachers' beliefs, few studies have been conducted on how and why tenured EFL teachers activate their beliefs within a context of strictly controlled curriculum and imposed language teacher education programmes and what influence this may have on their teaching practice. Specifically, when EFL teachers adapt the imposed communicative language teaching approach (CLA) in teaching grammar, tensions are bound to arise and influence their decisions regarding implementation of the proposed curriculum. The study addressed this gap and contributed more broadly to our understanding of how attention to teachers' beliefs and self-initiated models of professional development such as reflection could aid the effectiveness of top-down policies. This paper aimed at exploring the interplay between EFL teachers' beliefs about grammar teaching and their reported practices in public schools in Saudi Arabia, and the extent of influence of teacher education programmes in informing such beliefs. The investigation utilized semi-structured interviews with four EFL Saudi teachers. Qualitative data analysis revealed that despite the mandated CLA approach and training programmes, teachers reported dominant forms-focused (traditional) grammar instruction which was for the most part informed by consistent beliefs and influenced by prevailing contextual factors.
\end{abstract}

Index Terms-beliefs, communicative language approach, forms-focused grammar teaching, procedural knowledge, theoretical knowledge, language teacher education

\section{INTRODUCTION}

Over the past four decades, the repositioning of teachers' work into the educational research has sparked wider recognition of and interest in teachers' mental lives and practical knowledge. Hawkes and Olson (1984; Cited in Freeman, 2002) emphasized this shift in the history of research and argued that,

"Looking from a teacher-thinking perspective at teaching and learning, one is not so much striving for the disclosure of the effective teacher, but for the explanation and understanding of teaching processes as they are. After all, it is the teacher's subjective school-related knowledge which determines for the most part what happens in the classroom; whether the teacher can articulate her/his knowledge or not" (p.5).

In line with this, recent trends in second language teacher education (LTE) research have moved away from the behaviouristic paradigm, which focuses on the process-product or behaviours of language teaching, to the cognitivist and socio-constructivist paradigms where the focus is laid on teachers as the corner stone of the teaching process (e.g. Johnson, 1994; Peacock, 2001; Warford and Reefs, 2003; Borg, 2003; Freeman \& Johnston, 1998; Golombek, 1998; Phipps \& Borg, 2009). This move towards understanding teachers' mental lives is due to the recognition of teachers as decision makers, and who have their own belief systems which function as filters to their cognitive knowledge gained through in-service teacher education, college preparation and prior-experiences (Freeman \& Johnson, 1998; Farrell, 2005; Busch, 2010). Johnson (2006) indicates that research in the last four decades on teachers' cognition has significantly enhanced our understanding of the complexity of the teaching process.

Whilst previous research emphasized the role of novice teacher's beliefs in informing their teaching practices, little is known about how and why tenured EFL teachers perpetuate certain beliefs despite top-down professional development initiatives and what background sources underpin such beliefs. As regards the context of this study, when EFL teachers adapt the imposed CLA in teaching grammar, tensions are bound to arise and influence teachers' beliefs about the way they implement the proposed curriculum.

\section{LITERATURE REVIEW}

Although teachers' beliefs have been extensively researched, there is still no consensus on what the term means. Pajares (1992) described the term as "a messy construct" and this is in part due to the perceived complexities in terms of definition, understanding as well as the multidisciplinary nature the term embraces (p. 307). He spotted more than 17 'aliases' of beliefs which cynically 'travel in disguise'. These include "attitudes, values, judgments, axioms, opinions, ideology, perceptions, conceptions, conceptual systems, preconceptions, dispositions, implicit theories, explicit theories, 
personal theories, internal mental processes, action strategies, rules of practice, practical principles, perspectives, repertories of understanding, and social strategy, to name but a few that can be found in the literature" (ibid, p.309).

Despite the abundance of definitions of beliefs in the literature, the study was not meant to provide a discourse analysis or track the etymology of the different connotations of term. Rather, it adopted Borg's (2001) definition of 'beliefs' which provides concise and clear explanation of what the term means. A belief is "a proposition which may be unconsciously held, is evaluative in that it is accepted as true by the individual, and is therefore imbued with emotive commitment; further it serves as a guide to thought and behaviour" (p.186).

Borg's definition emphasizes salient denotations of 'beliefs' reported in the literature such as propositions, implicit theories and propositional knowledge which influence teachers' decision-making in their classrooms (Clarck and Peterson, 1986). Studying beliefs is part and parcel of second language teacher educators' repertoire because, without it, it will be difficult to fully understand the complexity of the teaching process. Awareness of teachers' beliefs does not only shape our knowledge about how they impact teaching but more importantly about how it informs teacher educators' decisions regarding what measures to be taken to promote teachers' professional growth. In this sense, beliefs show the extent to which teachers' teaching decisions may be informed by their cognitions or experiences and hence teach in accordance with their own theories. According to Peacock (2001) some of these beliefs might be 'detrimental' to the teaching or students' learning processes and hence intervention from astute teacher educators becomes necessary in a bid to change such beliefs. This conceptual framework informed my understanding and exploration of teachers' beliefs in the context of this study. Such conceptualisation did not only cover epistemological or subject-specific beliefs about grammar teaching, but also included broader areas of teachers' beliefs which contributed to deeper understanding of the interplay between teachers beliefs, teaching practices and the extent of harmony or tension between what teachers learned in teacher education programs and how their reported teaching practice looked like.

The importance of investigating teachers beliefs about grammar teaching stems from the fact that, to date, there is no consensus among language educators about how best to teach grammar (e.g. Littlewood, 1981; Ellis, 2001; Borg, 2003). For example, whether grammar should be formally taught is still an unresolved issue. Grammar teaching, therefore, might involve focus on forms (with an s), focus on form and focus on meaning or communication (Burgess \& Etherington, 2002). Focus on forms refers to the type of instruction that views language as discrete set of rules and that mastering them would be best attained through deductive teaching, use of terminologies and where accuracy is emphasized over fluency (Schmidt, 1994; Ellis, 2001). Focus on form, differs in that it is a feature of CLA where there is occasional reference to forms (Basturkmen et. al., 2004). Meaning-focused instruction derives from the CLA and involves implicit practice of grammar rules through communicative tasks or authentic situations, where the focus is on meaning and fluency rather than form and accuracy (Cele-Murcia \& Hilles, 1988; Ellis, 2006).

Therefore, grammar teaching can be described a 'messy construct' as well, and hence it is highly likely that teachers are left undecided about which approach(s) to survive with in teaching grammar lessons. For this reason, it is feared that teachers might default into the ways they were taught when they were language learners (Bosch, 2010). The polarity of traditional grammar teaching dominating the Arab world (Abdel Rauf, 2010) is one in a case and hence makes it vital to investigate the belief system of English language teachers as a potential perpetuator of the tradition.

Borg (2001) drew our attention to "the value of developing pedagogically oriented understandings of grammar among teachers, as opposed to conceptions of grammatical knowledge" which has no connection with real classroom practices (p.124). Borg' (1999, 2003) series of studies on teachers' beliefs about grammar teaching are highly influential in this terrain as it anchored beliefs to specific linguistic components such as grammar. However, it falls beyond the scope of this study to investigate real classroom practices. Meanwhile, the study aimed to explore the reported classroom practices through teachers' declarative knowledge about grammar teaching. It also explored LTE and other sources of developing such beliefs.

My approach to exploring this relationship between grammar teaching beliefs, practice and teacher education is informed by the following assertions (Pajares, 1992; Borg, 2006; Bosch, 2010, Basturkmen et. al., 2004), although precautions were taken to account for emergent data to fully shape my understanding of such relationship:

- Some beliefs are core while others are peripheral, and it is the scope of this study to concentrate the former.

- Beliefs filter pedagogical knowledge gained via LTE programmes.

- Beliefs highly influence practice, yet are not always congruent.

- Contextual factors (e.g. students, time) impact decision making more than beliefs do.

- Prior experiences as language learners shape teachers' beliefs.

\section{Sources of Grammar Teaching Beliefs}

Foreign language teachers enter the teaching profession with a knowledge base and expertise gained via a number of sources that contribute to their teaching practices in general and grammar instruction in particular. These range from their experiences as language learners whether in schools or colleges, to professional preparation, training and teaching experiences (Richards, 1998). The influence of prior language learning experiences on EFL teachers' knowledge system has been reported in a number of studies (e.g. Borg, 2003; Elbaz, 1981; Grossman, 1990; Freeman \& Johnson, 1998). For example, in reference to teachers' 'apprenticeship of observation' or the years individuals spent observing teachers and participating in classroom as students, Denscombe (1981; Cited in Freeman, 2002) stated that teachers' 'hidden 
pedagogy" "may do more than any professional preparation to shape how individuals actually teach" (p.7). For Grossman (1990), hidden pedagogy accumulates from a number of sources including subject-matter knowledge, professional development courses and classroom experience. Quite closely linked to the context of this study, Borg (1998) disseminated that teachers' decision-making in grammar teaching was influenced by their awareness of the context, pedagogical knowledge and subject-matter knowledge. Johnston and Goettsch (2000) also indicated that teacher's knowledge about grammar teaching was drawn from apprentice of observation as well as teaching experiences.

The professional preparation of teachers has surfaced in the literature as a major source impacting on the formulation of teachers' implicit theories. However, pre-service education seemed to have little effect on changing teachers' beliefs about language teaching. Peacock (2001) for example indicated that the learner teachers' belief system only slightly changed after their participation in the 3-year pre-service education. With regards to in-service education, Borg's (2011) longitudinal study showed that the 8-week training programme has a considerable impact on teachers' beliefs. Despite the fact the professional preparation is the most prominent source informing teachers' beliefs; its value is still debatable given the broad gap between propositional and procedural knowledge due to the power of wider socio-cultural and socio-political discursive realities (Ellis, 1990; Freeman \& Richards, 1998, Johnson, 2006). For example, students' expectations have been reported to guide grammar teaching practice (Borg, 2003). Other researchers have pointed out to the capacity of teachers' experiences when they were learners as another source of experience which informs their practice (e.g. Richards, 1998).

\section{CONTEXT OF THE PROBLEM}

This study came as a response to my long-standing interest in LTE. I worked as a teacher educator in the Ministry of Education, Saudi Arabia, for about six years whereby I undertook the responsibility of enhancing improvement of English language teaching and learning in public schools. I was expected to train, visit, observe and update teachers with articles in professional development and methods of language teaching, especially CLA.

From my personal experience, one thing I did not find an answer to, at the time, was the slow change, if any, of erroneous teaching assumptions and practices, when most of the teachers defaulted the bulk of their lessons into grammar instruction. No matter how hard I tried to train, observe and discuss implementation of CLA, teachers were less responsive and more "stubborn" to change. My personal observation is also advocated in recent quantitative studies which diagnosed the status of English language instruction in Saudi Arabia as product-focused where teachers were seen as implementers of top-down curriculum, and students were reported to have low English language proficiency (Grami, 2010; Al-Hazmi, 2003).

Additionally, teacher education programs in colleges have widened the rift between theoretical and procedural knowledge, where, apart from two methodology modules, their focus is on linguistics and literature (Al-Hazmi, 2003). Studies also reported insufficient pre- and in-services training programs for English language teachers provided by the ministry of education (Al-Ahaydib, 1986; Zaid, 1993, cited in Al-Hazmi, 2003).

\section{FocUs OF THE STUDY}

To my knowledge, mainstream studies were paradigmatically positivistic in which voices of grammar teachers were alienated. The relationship between LTE and grammar teaching is worth considering and researching where the voices of teachers are heard (Borg, 2003). Moreover, and more specifically in Arab countries, research intrusion is even more crucial in a world dominated by grammar translation methods of language teaching (Abdel Rauf, 2010). The need for research is still ongoing given the paucity of studies in LTE in Saudi Arabia.

Thus, it is the aim of this study to bridge the gap in mainstream research in teacher education in Saudi Arabia by taking a deeper stance into the theoretical and procedural knowledge of teachers about grammar teaching. Additionally, by relating beliefs to grammar teaching, this study bridges the gap in previous research where the focus of beliefs is generic in the most part (Borg, 2003).

\section{QUESTIONS OF THE STUdY}

The study aimed to explore English language teachers beliefs about grammar teaching and their practice through teachers' self-reports. Additionally it sought to elucidate the influential sources that shaped their beliefs. So, the following questions summarize the purpose of the study.

1- What are the beliefs about grammar teaching that English language teachers hold? And what is the underlying rational for each belief?

2- To what extent do teachers' reported practices align with their beliefs?

3- What are the sources through which teachers developed such beliefs about grammar teaching?

\section{Methodology}

The exploration of teacher's beliefs about grammar teaching in this study is informed by the interpretive paradigm. Within this paradigm, the researcher's role is to understand the social phenomena by describing the intentions, thoughts 
and beliefs of the participants, where knowledge is viewed as subjective reality and socially constructed (Cohen et al., 2000; Crotty, 1998). The epistemology of this framework calls for interpretation of human behaviour by understanding the reasons behind doing it (Dunne et al., 2005). In this regard, my aim of the study was to construct a realization of how Saudi EFL teachers approach grammar teaching, from their own perspectives, and what LTE sources informed such experiences.

This study bridged the gap in previous research where, as far as I know, qualitative studies on grammar teaching beliefs have never been conducted in Saudi Arabia.

\section{A. Participants}

The participants were four male Saudi EFL teachers in public schools (see table 1). They all had a major in English language teaching and their teaching experiences ranged from 3 to10 years. My approach to choosing this number was based on convenience sampling, a process of selecting participants based on availability, ease, speed, and low cost (Marshal, 1996). Since the four teachers opted to participate voluntarily in the probing process, this number is also convenient to the purpose of my study, as it is exploratory and does not aim to generalize the results.

It should also be pointed out that the research ethical bold lines were taken into consideration. The participants were reassured that they were under no obligation to participate. Additionally, to make them aware of the background about the interview, they were e-mailed a two-page document about grammar teaching beliefs. They were also made aware of their rights in terms of consent, privacy, and confidentiality prior to conducting the study. Pseudonyms (teacher X) were used to protect the participants' identities.

TABLE 1.

DEMOGRAPHIC INFORMATION ABOUT THE PARTICIPANTS

\begin{tabular}{|l|l|l|l|l|l|}
\hline Participants & Major & $\begin{array}{l}\text { Institution of } \\
\text { Graduation }\end{array}$ & $\begin{array}{l}\text { Teaching } \\
\text { Experience }\end{array}$ & Level of Students & $\begin{array}{l}\text { Professional Development } \\
\text { activities }\end{array}$ \\
\hline Teacher (1) & $\begin{array}{l}\text { B.A. Teaching } \\
\text { English } \\
\text { Language in } \\
\text { Saudi Arabia }\end{array}$ & Teachers' College & 3 Years & Intermediate & -------------- \\
& $\begin{array}{l}\text { B.A. Teaching } \\
\text { English } \\
\text { Language in } \\
\text { Saudi Arabia }\end{array}$ & Teachers' College & 3 Years & $\begin{array}{l}\text { Intermediate } \\
+\end{array}$ & Training Programs \\
& $\begin{array}{l}\text { B.A. English } \\
\text { language with } \\
\text { Educational } \\
\text { Preparation }\end{array}$ & University & 10 Yeas & $\begin{array}{l}\text { Intermediate } \\
+ \\
\text { Secondary }\end{array}$ & $\begin{array}{l}\text { Training (home + UK.), } \\
\text { Peer-Observation }\end{array}$ \\
\hline Teacher (3) & $\begin{array}{l}\text { B.A. English } \\
\text { language with } \\
\text { Educational } \\
\text { Preparation }\end{array}$ & University & 10 Yeas & $\begin{array}{l}\text { Intermediate } \\
+ \\
\text { Secondary }\end{array}$ & $\begin{array}{l}\text { Training, } \\
\text { Peer-Observation }\end{array}$ \\
\hline
\end{tabular}

\section{B. Data Collection Method}

Driven by the interpretive paradigm which calls for qualitative data collection methods, semi-structured interview were undertaken with the informants to understand how they approached grammar teaching and what sources of LTE informed their teaching practices. The interviews served as an elicitation instrument of beliefs and at the same time as a self-report about teacher's grammar teaching practices. Polkinghorne (2005) stated that, the latter helps the "researcher to produce a core description" of the teachers' reported accounts of their teaching experiences (p.138).

An interview protocol was devised in order to guide the interview but not control it. The participants were given room to express their thoughts and ideas in a friendly manner. The protocol comprised four elements:

1- demographic information about the participants,

2- beliefs about foreign language learning and teaching,

3- beliefs about grammar teaching, and

4- sources of teachers knowledge and experiences.

It should be noted that the third component adopted Borg's outline about how and why teachers teach grammar (Borg, 2003. p165-166). The second and fourth components were developed based on my experience and on the literature review. The sequence of the questions is based on the idea that beliefs about language learning and teaching inform grammar teaching. However, it falls beyond the scope of this study to investigate in depth general language beliefs.

Within grammar teaching, four questions covered the content to be taught, lesson structure, strategies to teaching grammar and evaluation. The fourth question probed sources of LTD that impact teachers' teaching practice.

After the interview had been piloted, I set up convenient times for each respondent to conduct the interview using VOI (voice over the internet) with three interviewees and a phone call with one participant. Each interview lasted from 30 to 50 minutes. The interviews were digitally recorded and electronically saved for later stages of retrieval and transcription. After that, I transcribed the data verbatim, returned it back to each participant with the pseudonyms (Teacher X) for cross-checking. 
Finally, it should be noted that only one participant returned back his interview transcription with confirmation, whereas the other three participants replied over the phone that they approved the transcripts. Then, I was ready to undertake data analysis.

\section{Data Analysis}

The interviews produced a large quantity of very interesting data in relation to questions of the study. However, for the purposes of this paper and bearing in mind the word limit, I intended to focus on beliefs about grammar teaching and LTE sources of beliefs.

I utilized both approaches of data analysis; deductive and inductive. The former involves approaching the data with predetermined codes known as 'priori' which served as a manual whereby "analysis normally starts with some predefined codes intended to help guide analysis" (Waring \& Wainwright, 2008, P.87). The latter, inductive analysis was undertaken as a complement to the deductive analysis to "allow for themes to emerge direct from the data" (Fereday\& Muir-Cochrane, 2006, p.4). I employed this method to make my data analysis trustworthy, credible and far from bias (Golafshani, 2003).

So, the first task of data coding was based on a template or priori of four general categories for grammar teaching and three for LTE sources. These categories were driven out of current grammar teaching research and beliefs about grammar teaching (e.g., Borg, 1998, 2003; Ellis, 1992, 2006). Such categories included a number of terms (meaning/forms-focused instruction, inductive/deductive instruction, presentation, practice, evaluation, grammatical errors and use of grammatical terminology, etc.) which were tabulated in the interview protocol and functioned as guide for analysis as well. This, however, did not mean imposing the priori codes solely on the data, as Silverman (2000) warned against. Hence, in the second task of data coding, I was aware and took all precautions to give room for emergent data to add, amend or alter the predefined codes which eventually did.

I went through each set of data to look for recurrent themes and code them under each category of the template. I reread again to look for new sub-categories which were abundant in the data and coded the themes under each subcategory. The third-time reading was for sorting the codes into the data for quoting. For example, the "grammar teaching" category generated seven sub-categories and each sub-category included a number of themes:

\section{FINDINGS}

The analysis of teachers' beliefs about grammar teaching and their teaching practices were both aligned and paradoxical. Where aligned, all four teachers' reported grammar instruction was forms-focused; they used L1, terminologies, and corrected errors. Where paradoxical, teachers' beliefs included meaning-focused and communication oriented practices.

The consistency of beliefs and teaching practices stems from harmony between theoretical knowledge and contextual factors. The paradox, on the other hand, is caused by the capacity of contextual factors on the belief system which obliged teachers to submit to. Hence, contextual factors shape the belief system. As far as sources of beliefs are concerned, college preparation and training represented the most effective sources for beliefs about grammar teaching.

\section{A. Beliefs about Grammar Teaching}

Generally speaking, the participants' belief system was dominated by a mechanical forms-focused approach to grammar teaching. There are however some reported meaning-focused grammar instruction. These will be illustrated below.

\section{B. Forms-focused Grammar Instruction}

Explicit grammar teaching appeared in the data as the core teaching strategy for grammar instruction among all the participants. One teacher for example starts his grammar lesson by writing an outline of the form of the grammar rule on the board so neatly, followed by teacher's led explanation.

"My way, when I teach the present continuous, I write on the board present continuous. After that, I use colours to write the rule for example, I put pronouns, in blue, after that I put verbs in blue...and just (verb+ing) by another colour" (Teacher 1).

It seems that this teacher is concerned with the grammar rule based on his belief that successful grammar learning entails "acquiring the language" (Teacher 1). This was clear in his justification of explicit teaching of the present continuous tense. He stressed that, when students are taught grammar explicitly, they "understand or remember when they go home, oh,,, my teacher put he pronoun in a specific colour". Teacher (2) used more or less the same outline and was also driven by the belief that grammar teaching is important because if students "learn grammar the correct way, they would speak $100 \%$ correctly"

"In grammar lessons, I put the grammar at the general way.... and sometimes I use (the following approach) like 'the verb to be lesson':

I takes am.

He and she take is 
After that, I may use I, we or they (substitution drills). I take the lesson the easy way and end it the hard way. They give me examples, they use examples... they say fluently" (Teacher 2).

Forms-focused instruction featured so intensely in one of the teachers' reported practice when he strongly opposed meaning-focused phenomenon once it was mentioned to him.

"No, no, according to the meaning, I don't concentrate on the meaning at all. The most important thing is the form" (Teacher 4).

The lesson structure follows a consistent pattern for three teachers i.e. the lesson usually starts with illustration of rules on board, use of colours, explanation of rules, and use of Arabic language, understanding action by students, recognition and substitution drills, repetition drills, and repetition of chunks of the language. This is typically what Schmidt (1994) called "consciousness raising" in grammar instruction. Teachers are obsessed with explaining grammatical rules for their students, assuming that knowing the rules leads to correct language use. However, one teacher, although frequently uses forms-focused grammar instruction, pointed out that he used meaning-focused strategy in revision lessons. This will now be explored.

\section{Meaning-focused Grammar Instruction}

Implicit grammar teaching surfaced in one of the participants' reported practices as a conceptual teaching practice but not a procedural one. For example, he emphasized situational language teaching and the importance of context to introduce grammar rules which can supposedly be done through discovery learning, and pair/group work. His theory of teaching grammar was for his students "to pick it up indirectly".

"Usually, when I want to teach grammar to my students, I begin by setting the scene either with a short a story or some activities that may have the same pattern that is introduced to them, give them some cards with some chunks of the language being introduced, with sentences, with colours" (Teacher 3).

His theory of teaching grammar, however, is idealistic rather than realistic. There were many conflicts that intercepted his aspiration and, had there been, were kept minimally. For example, he retracted his position from a meaning-focused and followed a forms-focused grammar instruction in all the lessons but revisions. It seems that the availability of time or lack of it is a critical factor in choosing which one approach to follow. Lack of time was reported to be one of the reasons which compel the teacher to default into explicit grammar teaching.

"If, for example, I am teaching them the present tense for the first time, I'll teach it explicitly. If, on the other hand, it is a revision or remedial work, I'll teach them implicitly just to save the time "(Teacher 3).

These incidents are telling of the superficial and secondary role of implicit grammar teaching, where its use is reduced to revision lessons. However, this is a good indication that this teacher is aware of counter-grammar translation teaching approaches dominant in the Arab world as reported earlier, but may be squeezed to the minimal use for logistic obstacles in terms of time and other parameters. These are regarded as contextual factors which exert decision making and will be discussed at a later stage.

Another inference is the capacity of teacher education on quality instruction and hoped change in grammar teaching. It seems that teacher (3) has "tensions" between the repertoire of pedagogical knowledge and contextual constraints. However, Teacher (3) differs from all the other interviewees in this study in his exposure to the various professional development programs he had undertaken. Important among these is the one-month training course he had in Leeds, UK, as well as many training programs in his home country.

\section{Use of First Language in Grammar Teaching}

The use of teachers' mother tongue (Arabic Language) featured categorically among the three participants' reported grammar teaching practices. The use of L1 was reported to be used in giving instructions to students as well as in transferring the meaning of grammar rules from L2 to L1. For example, Teacher (1) stated his frequent use of Arabic in grammar lesson as a means for simplifying the rules for his students.

"I mix Arabic and English.... Because I explain for students "town" in English but students don't understand....for this reason I have to use Arabic" (Teacher 1).

Initially, I thought that this teacher used L1 to facilitate learning vocabularies "town in this case". However, when I asked him for clarification he indicated that in grammar he had to use "both languages because all my students live in village and as their environment, they see English strange language" (Teacher 1).

Another teacher mentioned using Arabic language in grammar teaching for classroom management purposes. If he did not use L1, he would not expect his students to learn the grammar at hand. Moreover this teacher advocated using L1 in grammar lessons, but saw no point of using the mother tongue in other skills such as speaking or listening. This was based on the assumption that using L1 in grammar teaching would make English language easier for the students:

"I can't give him the grammar in English, all in English, because they will not know very well. But, to make things easier, I write the rule in Arabic (pronoun + verb + complement) ". (Teacher 2)

Teacher (4) blamed his use of Arabic language in grammar lessons on the inevitable code-switching or transferability from English to Arabic, since he is a native Arabic language speaker. However, he theorized its efficiency had it been reduced to the minimum.

"It is efficient if we minimize the Arabic use to 5\%. So, you can use it with modals only to convey the meaning of an abstract word like ability” (Teacher 4). 
Therefore, where forms-focused grammar teaching is exploited, L1 was seen as one of the basic strategies of facilitating English grammar teaching where English is taught as a foreign language.

\section{E. Use of Grammatical Terminologies}

One of the categories that surfaced in the data was teachers' divergent views about the use of grammatical terminologies. Two teachers emphasized the importance of using grammatical terms in their grammar teaching practices.

"Yeah, I tell them (students) before (the lesson).. Today we are going to know how to give sentences in the future tense." (Teacher 2).

Another teacher exempted its use with beginners, but regarded terminologies important to be used with adult language learners. Actually, for this teacher, age factor determined the kind of instruction he decided to follow. He reiterated that adult learners have the capacity to understand grammatical terminology but not beginners.

"I'll teach them (adults) the same way (as beginners) but, I'll give them terminologies" (Teacher 3).

However, it should be pointed out that there is no indication of the reasons behind teachers' use of terminologies in grammar instruction. What we know, though, is the capacity of its use as an indicator of explicit grammar instruction (Phipps \& Borg, 2009).

\section{F. Errors}

It could be well said that errors were seen by all the teachers in this study as indicators of bad linguistic behaviors that tell about how good or shaky the learners' understanding of the grammatical pattern is. This is in line with formsfocused approach which emphasizes correct production of language and is intolerant of grammatical errors (Schmidt, 1994). In terms of speaking and writing, teachers in this study demanded their students produce grammatically correct sentences, or else they will be corrected.

"I have to stop the students a lot of times and they have to say the good thing, correct thing" (Teacher 2).

The perceived belief behind correcting mistakes is that grammar is regarded as the base of learning and need to be guarded against flaws. This job can be done only by language teachers.

"So, you have to stop them and tell them the right..(Correct them)..Because you are the teachers" (Teacher 2).

Another teacher had to correct grammatical mistakes, because "if students cannot understand what is wrong, they will show to him mistakes" (teacher 1). He meant that mistakes should be eradicated; otherwise they would be indicators of bad learning or failure to learn grammar. This is one of the tenets of anti-communicative approach movement that claim fossilization to be one of the aftermaths of errors tolerance (Ellis, 2006). This was also advocated by another teacher who articulated clear reasons underlying his beliefs about correcting grammatical errors:

"My theory is that when I correct their [students] mistakes they will learn the grammar point in question" (Teacher 4).

Contrary to the above view about error correction, Teacher (3) partially condemned explicit error correction, especially for beginners, and restricted its use till the end of the grammar lessons. He added that he will locate the mistakes and spring them back to the students at the end of the lesson to make them aware of their mistakes.

"I'll let them to communicate with their colleagues.... and I will just summarize the main mistakes they fell in.. I'll ask them to be conscious about their mistakes" (Teacher 3).

His underlying belief was that intrusion by the teacher during the course of communication will stop the flow of meaning negotiation and hence is better delayed to a later stage in the lesson.

"Because I agree with those linguists who say that correction to beginners is harmful for the learning situation. So, I delay the correction till the end" (Teacher 3 ).

Yet, this teacher believes in the role of errors as signs of bad learning habits, and therefore has to be eliminated.

\section{G. Sources of Beliefs}

This category refers to the LTE sources that informed grammar teaching practices. Although sources of beliefs involve received knowledge (e.g. training) as well as personal knowledge(e.g. critical reflection, experience) in addition to others such as contextual factors (Richards, 1998), the participants of this study reported one-sided, top-down institutional preparation and development programmes initiated by colleges or the ministry of education. All the blame was levelled at both institutions for not providing them with sufficient training programmes and few supervisors' visits. Three teachers complained about these issues with a sigh of relief.

"When I was a learner teacher in college, I had no training, just a supervisor came to observe me in the classroom, and did nothing apart form highlighting my pronunciation or grammatical mistakes. As a teacher, in (X) educational directorate, I haven't had any training, no supervisor has visited me yet" Teacher (1).

The sources of knowledge that bear on teachers' belief system about grammar teaching, featured as theoretical and practical.

\section{H. College Preparation}

Teachers reported that college preparation was mostly theoretically-oriented and did not tell much about classroom practices. 
"Yeah, I know a lot of things from college...but the big problem is that I forgot it or sometimes you cannot use because the background of the students is Zero. So, I cannot use a lot of things that I learnt at college" (Teacher 2).

Another teacher stated that college preparation did not provide classroom practice:

"Only the courses were about English literature and second language acquisition..... but it did no provide us with solutions to the problems in the classroom...." (Teacher1).

However, for another teacher, the theoretical knowledge gained from courses in college pertained to his effective classroom practices, despite the quality of training he had been through.

"......I think, those two modules I studied at my college affected my teaching styles and strategies" (Teacher 3).

\section{In-service Training}

Two Teachers reported training to be one of the main sources of informing their grammar teaching practices. For example, one teacher, although undertook a one-week preparation course, eulogised the benefits of training.

"For training, yeah... I took a lot of benefit ......... know how to prepare very well, respect my students. So, if you are not prepared very well..... you'll be embarrassed" (Teacher 2).

Teacher (4), although stressed the role of training that informed his teaching practices, he confessed that they were not professionally related to English language teaching. Rather, they were introduced in Arabic language and were about pedagogical knowledge of teaching in general. He was quite happy with the pay-offs of classroom observation and post-observation interviews with one of his supervisors as far more beneficial for his professional growth than the one-size-fits-all training sessions because such observation provided him with context-specific and classroom survival strategies.

"...I do not remember that I got this experience from college...But, training, yeah, is very important. And when I sit with the $X$ supervisor, this is training... because we are talking with a motivation.... we are fetching solutions" (Teacher 4).

However, it is clear that teachers referred to generic pedagogical knowledge, gained via training (e.g. lesson planning), rather than knowledge about grammar teaching. Quite interestingly, teacher (3) who had undertook intensive ELT programmes and demonstrated interesting theoretical pedagogical knowledge, was quite skeptical about assigning his pedagogical background to training. He was very obsessed with the two modules that were introduced as a requirement for obtaining the educational preparation honoured as a bachelor of art in teaching English language.

"I cannot decide which aspect is responsible for my knowledge, whether my experience, college or training. But, I think, those two modules I studied at my college affected my teaching styles and strategies" (Teacher 3).

\section{J. Contextual Factors}

Contextual factors emerged as a critical source that informed practice more than TE programmes. The reason behind this conclusion is that although teachers mentioned TE programmes that were introduced in college or in-service training, they failed to identify the matching teaching practice. Contextual factors on the other hand, were reported to be decisive in guiding practice. For example, students' low levels, fixed-chairs classrooms, time and tests influenced teachers to teach consistently. So, teacher (2) tended to ignore difficult grammar rules as a compromise to the low levels of the students.

"So, I sometimes never teach some grammar, I think it is difficult for the students or they don't use it" Teacher (2).

Teacher (1) exploited speaking and listening lessons to teach grammar due to lack of instructional materials or because of the status of his students in rural areas.

".... because the ministry does not give us teaching materials like tapes we use in conversation....in every lesson, I focus on grammar, regardless of other skills in the same lesson, " (Teacher 1).

Teacher (3) mentioned time demands as well as rigid syllabus as determiners of forms-focused teaching which is his second preference.

"I'll teach it explicitly, I think just to save time" (Teacher 3).

Teacher (4) mentioned students' lack of motivation as a restraint to his aspirations of meaning-focused grammar instruction.

"But, about the grammar lesson, I think there is no practice... we cannot, and the reason behind that is the students' lack of motivation... they do not want to learn. I just concentrate on how the exam will come" Teacher (4)

To conclude, teaching grammar was in the most part guided by emergent contextual factors that obliged teachers to adopt explicit grammar teaching which has eventually shaped the belief that this is the best way to teach grammar.

\section{DISCUSSION}

By saying that grammar translation method is 'still alive in Arab countries, Abdel Rauf (2009) struck a note. Grammar instruction, revealed by this study, is dominated by a teacher-centred, forms-focused approach where the target is comprehension of discrete rules and production of correct forms rather than communication or meaningful language. The use of first language surfaced among three teachers as a very important strategy to facilitate grammar learning, hence not far from grammar translation methods (Ellis, 2006). This episode shows a great degree of agreement between teachers' beliefs and reported practices. The underlying beliefs of explicit grammar teaching related to the 
potential learning outcomes such as grammar comprehension and correct sentence or language production. This consistency between beliefs and practices was evident in teachers' reported practices; three teachers believed that grammar should only be taught explicitly and articulated clear reasons about such beliefs. Hence, factors like time, students' age, students' expectations, low levels, difficult grammar rules, and lack of materials exerted decision making by teachers to accept forms-focused instruction as a suitable grammar teaching method. These are regarded as contextual factors that impact the belief system, and are widely recognized in grammar teaching research to guide teachers' decision making (e.g. Andrews, 2003; Borg, 1999, 2001; Freeman \& Richards, 1996, Johnson, 2006). It could be well said that teachers' beliefs and practice ran defiantly against the CLA endorsed by the imposed curriculum and professional development activities.

It seems that top-down professional development approaches were too preoccupied with knowledge transmission from experts to teachers and downplayed the influence of the wider socio-political and socio-cultural realities on teachers' beliefs and practices. It is argued though that for professional development to prosper in such a controlled context, teachers' beliefs should be recognised and clearly articulated so as to aid the effectiveness of top-downness.

Conversely, there was a conflicting episode between what one teacher believed about grammar teaching and his reported practices. For one teacher, grammar teaching was theorized to involve contextualization of rules, communicative tasks, pair/group work, and implicit grammar instruction. Practically, however, grammar teaching entailed rule presentation, practice and production (PPP) where the focus is on correctness or accuracy of production, all of which represent different facets of the forms-focused instruction. This is also widely recognized in grammar teaching research (e.g. Basturkmen et al., 2005; Farrell, 2005; Phipps \& Borg, 2009). This is another indication that despite teachers' willingness to implement communication-oriented activities, socio-cultural and socio-political factors could impede such ambitions and make teachers revert to the status quo for guiding their practice.

With regards to the other sources that informed the belief system about grammar teaching, college or university preparation as well as training represented the channels through which teachers gained such beliefs (e.g. Borg, 2003; Elbaz, 1981; Grossman, 1990; Freeman \& Johnson, 1998). However, the latter had been granted the rule of thumb for providing general pedagogical knowledge about teaching such as classroom management and lesson preparation. The former provided teachers with general knowledge about second language acquisition and teaching methodologies. Practice rather than theoretical knowledge, therefore, was a missing theme for teachers and was clearly voiced in this study. This is a challenge that LTE need to resolve if successful implementation is desired. The participants complained about the polarity of theoretical knowledge about language teaching introduced by colleges and universities. They expressed their anguish at missing the chances to be guided through practice rather than theoretical knowledge. I would argue that what teachers actually need, in addition to theoretical background, is survival tips that would help them in real teaching practices.

Additionally, the role LTE played in actually preparing prospective English language teachers is questionable. That is, apart from one teacher in this study, it was not easy to identify instances of theoretical knowledge about grammar pedagogy. Terms like form/meaning-focused instruction, accuracy and fluency were not clear to the teachers. Once I mentioned such terms, Teacher (1) for example, asked me to clarify them. Others were not able to name substitution drills, role-plays, guided-activities, communicative task, deductive and inductive teaching (Teacher 2, Teacher 3). Another teacher could not describe grammatical terms like short forms or contracted forms in natural communication. They described the term with sentences instead (e.g. I am= I'm).

It could be the possibility that the current theoretical orientation of LTE contributed to a large extent to teachers' entanglement into contextual factors that intercepted their theoretical knowledge and informed their current belief system. This led the teachers to resort to their inclinations about how to teach grammar or default into ways they experienced as learners and take them for granted. For example, all teachers followed the same rigid forms-focused approach with slight differences spotted in reported teaching practices. This means that either LTE prepared teachers to teach grammar explicitly, or that the teachers followed suit the way they were taught with. This entanglement, though, can be mediated by LTE programmes if practice is taken into consideration. This was evident with Teacher 3 who demonstrated quite solid knowledge about grammar teaching approaches which were supposedly gained via a series of intensive LTE programmes he has been through.

Another aspect that should be emphasized is the evident teachers' thirst for top-down LTE programmes. In order to gain fruitful development, LTE programmes need to enhance teachers' self-initiated or bottom-up professional development activities such as action research, peer-observation, self-monitoring and journal writing. Teachers need to get involved in diagnosing, assessing and seeking solutions to their teaching practices, on their own as decision makers.

\section{CONCLUSION}

This study has clear implications for LTE and research methodology. I would argue that it is not always the case that top-down LTE programmes are the only source of knowledge underlying classroom teaching practices. Beliefs should be acknowledged as more powerful and have more impact on teaching. Hence, in-service teacher education programmes could address any foreseeable incompatibility between teachers' beliefs and desired practices by providing teachers with the chances to reflect on their beliefs and classroom practices. Additionally, contextual factors intercept as a source and contribute to the formulation of the belief system which might alter altogether or filter knowledge 
gained from LTE. Such challenges need to be addressed when planning training programmes. Moreover, qualitative studies need to be undertaken to help tenured teachers elucidate their belief system, explore the relationship between what they belief, know and what they actually instigate in classroom, and reveal the contextual factors underlying their beliefs.

LTE programmes also, besides literary preparing or equipping teachers professionally, have the responsibility to encourage them to explore their beliefs, practices and initiate required professional developments rather than desperately wait for the TE programmes to work its magic to change grammar teaching practices among English Language teachers.

\section{REFERENCES}

[1] Abdel Rauf, A. (2010). Grammar-translation method: Still alive in Arab TEFL classroom. TESOL Arabia Perspectives 17. 1, 13-18.

[2] Al-Hazmi, S. (2003). EFL Teacher preparation programs in Saudi Arabia: Trends and challenges. TESOL Quarterly 37.2 , 341 344.

[3] Andrews, S. (2003). Just like instant noodles: L2 teachers and their beliefs about grammar pedagogy. Teachers and Teaching 9. $4,351-375$.

[4] Basturkmen, H., Loewen, S. \& Ellis, R. (2004). Teachers' stated beliefs about incidental focus on form in their classroom practices. Applied Linguistics 25. 2, 243-272.

[5] Borg, M. (2001). Key Concepts: Teachers' beliefs. ELT Journal 55. 2, 186-188.

[6] Borg, S. (1999). Teachers' theories in grammar teaching. ELT Journal 53. 3, 157-167.

[7] Borg, S. (2001). Self-perception and practice in teaching grammar. ELT Journal 55. 1, 21-29.

[8] Borg, S. (2003). Teacher cognition in language teaching: a review of research on what language teachers think, know, believe and do. Language Teaching 39. 6, 81-109.

[9] Borg, S. (2006). Teacher Cognition and Language Education. Continuum, London.

[10] Burgess, J. \& S. Etherington. (2002). Focus on grammatical form: Explicit or Implicit? System 30. 4, 433-458.

[11] Busch, D. (2010). Pre-service teacher beliefs about language learning: The second language acquisition course as an agent for change. Language Teaching Research, 14. 3, 318-337.

[12] Celce-Murcia, M. \& H. Sharon. (1988). Techniques and Resources in Teaching Grammar. Oxford, UK: Oxford University Press.

[13] Cohen, L., L. Manion \& K. Morrison. (2000). Research Methods in Education (5th edn.). London: Routledge Falmer.

[14] Crotty, M. (1998). The foundations of social research: Meaning and perspective in the research process. London: Sage Publications.

[15] Dunne, M., J. Pryor \& P. Yates. (2005). Becoming a Researcher: A companion to the research process. Maidenhead, England: Open University Press.

[16] Elbaz, F. (1981). The teacher's practical knowledge: Report of a case study. Curriculum Inquiry 11. $43-71$.

[17] Ellis, R. (1998). Teaching and research: options in grammar teaching. TESOL Quarterly 32. 1, 39 - 60.

[18] Farrell, T. S. C. (2005). Conceptions of grammar teaching: A case study of teachers' beliefs and classroom practices. TESL-EJ, 9 (2). http://www.tesl-ej.org/wordpress/issues/volume9/ej34/ej34a9/ (accessed 28/12/2011).

[19] Fereday, J. \& E. Muir-Cochrane. (2006). Demonstrating rigor using thematic analysis: A hybrid approach of inductive and deductive coding and theme development. International Journal of Qualitative Methods 5. 1, 1-16.

[20] Fotos, S. (1994). Integrating grammar instruction and communicative language use through grammar consciousness-raising tasks. TESOL Quarterly 28. 323-351.

[21] Freeman, D. \& K. E. Johnson. (1998). Reconceptualising the knowledge-base of language teacher education. TESOL Quarterly 32. 3, 397-417.

[22] Freeman, D. (2002). The hidden side of the work: Teacher knowledge and learning to teach. A perspective from North American educational research on teacher education in English language teaching. Language Teaching. 35, 1-13.

[23] Freeman, D. \& J. Richards. (eds.) (1996). Teacher learning in language teaching. Cambridge: Cambridge University Press.

[24] Golafshani, N. (2003). Understanding reliability and validity in qualitative research. The Qualitative Report 8. 4, $597-607$. http://www.nova.edu/ssss/QR/QR8-4/golafshani.pdf (accessed 28/12/2011).

[25] Golombek, P. (1998). A study of language teachers' personal practical knowledge. TESOL Quarterly 32. 3, 447-464.

[26] Grami, M. A. G. (2010). The Effects of Integrating Peer Feedback into University-Level ESL Writing Curriculum: A Comparative Study in a Saudi Context. Unpublished PhD Thesis, Newcastle University. https://theses.ncl.ac.uk/dspace/handle/10443/933 (accessed 28/11/2011).

[27] Grossman, P. L. (1990). The making of a teacher: Teacher knowledge and teacher education. New York: Teachers College Press.

[28] Johnson, B. \& K. Goettsch. (2000). In search of the knowledge base of language teaching: Explanations by experienced teachers. Canadian Modern Language Review, 56. 437-468.

[29] Johnson, K. E. (1994). The emerging beliefs and instructional practices of pre-service English as second language teachers. Teaching and Teacher Education, 10. 4, 439-52.

[30] Johnson, K. E. (2006). The sociocultural turn and its challenges for second language teacher education. TESOL Quarterly 40.1 , 235-257.

[31] Marshall, M. N. (1996). Sampling for qualitative research. Family Practice 13. 6, 522-525.

[32] Pajares, F. (1992). Teachers' beliefs and educational research: clearing up a messy construct. Review of Educational Research 62. 2, 307-332. 
[33] Peacock, M. (2001). Pre-service ESL teachers' beliefs about second language learning: A longitudinal study. System 29. $177-$ 195.

[34] Phipps, S. \& S. Borg. (2009). Exploring tensions between teachers' grammar teaching beliefs and practices. System 37. 3 , 380 390.

[35] Polkinghorne, D. E. (2005). Language and meaning: Data collection in qualitative research. Journal of Counselling Psychology 52. 2, 137-145.

[36] Richards, J. C. (1998). Beyond training: Perspectives on language teacher education. Cambridge: Cambridge University Press.

[37] Schmidt, R. (1994).The role of consciousness in second language learning. Applied Linguistics 11. 2, 17-46.

[38] Shulman, L. S. (1987). Knowledge and teaching: Foundations of the new reform. Harvard Educational Review 57. 1, 1-22.

[39] Silverman, D. (2000). Doing qualitative research. A practical handbook. Sage, London.

[40] Warford, M. K. \& J. Reeves. (2003). Falling into it: Novice TESOL teacher thinking. Teachers and Teaching: Theory and Practice 9. 1, 47-65.

[41] Waring, T.W. \& D. Wainwright. (2008). Innovative developments in the use of Template Analysis: Two comparative case studies from the field. Electronic Journal of Business Research Methods 6. 1, 85-94. www.ejbrm.com (accessed 17/01/2013).

Hussein M. Assalahi received his B.A. in English Language with educational preparation form Umm Al-Qura University, Saudi Arabia. He got his M.A. in Curriculum and English Language Instruction from the same university. He is an ED.D TESOL candidate at the University of Exeter, UK. He is a TESOL lecturer at King Abdulaziz University in Saudi Arabia. His areas of interest are: second language teacher education, critical applied linguistics and second language acquisition. 